\title{
THE EFFECT OF GOOD CORPORATE GOVERNANCE AND TRI HITA KARANA CULTURE ON THE QUALITY OF FINANCIAL REPORTING
}

\author{
Indriyani Ni Made Vita*, Putri Igam Asri Dwija, Suardikha I Made Sadha, \\ Wirajaya I Gde Ary \\ Master's Program of Accounting, Faculty of Economics and Business, \\ University of Udayana, Indonesia \\ *E-mail: made.vita@yahoo.co.id
}

\begin{abstract}
This study examines the effect of Good Corporate Governance (GCG) and Tri Hita Karana (THK) Culture on the Quality of Financial Reporting conducted on money changer in Badung Regency. The analysis technique used in this research is multiple linear regression analysis. This study only got questionnaires that returned as much as $82 \%$ of the questionnaires distributed in 88 companies. The questionnaire was filled by the respondents of the study consisting of owner, manager, accounting and teller. Based on data from the questionnaire, the researched conclusions are obtained that support the hypothesis, where $\mathrm{H}_{1}$ accepted which means GCG positively affect the quality of financial reporting. Likewise, $\mathrm{H}_{2}$ is accepted which means THK culture has a positive influence on the quality of financial reporting.
\end{abstract}

\section{KEY WORDS}

Good corporate governance, tri hita karana culture, financial reporting, company.

Good Corporate Governance (GCG) becomes a very important thing for the company. Although the existence of GCG is quite long, it is still an interesting study to do (Putri, 2012). Todorovic (2013), GCG can help in the prevention of corporate scandals, fraud and crime. GCG also related with how the principal can believe that agents will benefit them, believing that agencies do not embezzle and invest their funds in projects that do not benefit the principal (Shleifer and Vishny, 1997). Chairman of the Board of Commissioners of the Financial Services Authority, Muliaman Hadad stated that GCG guarantees business development and is essential if business sustainability is maintained (Afrianto, 2017). Muliaman also said that Indonesia is currently included in the lowest rank on good governance in Southeast Asia.

In addition to good corporate governance, it is also necessary to apply local cultures such as local wisdom attached to individuals (Putri et al., 2017). The role of culture in the last decade has received much attention from economists because the economic interaction can not be separated from the culture owned by various countries in the world (Sudarma, 2013). The cultural contribution in understanding economic phenomena suggests that cultural hypotheses are important for explaining fundamental economic problems (Guiso et al., 2008, 2009). Another view suggests by Tabellini (2008) that culture is the main determinant of economic development and empirical studies of culture also have consequences in financial literature, capital market phenomena, and corporate capital structures (Chui et al., 2002) and industrial development in mixed information (Huang, 2008). In addition, Wirajaya et al. (2014), states that accountability practices are formed from philosophical, cultural and religious configurations. In this study, the configuration is shown in the THK culture. Where, the value in THK culture teaches humans to always maintain harmony between human relationships, human with the environment, and human with God.

This study uses an authorized money changer in Badung regency. This is because money changers are particularly vulnerable to money laundering, embezzlement, fraud, financial report manipulation and have been infiltrated by drug dealers and corrupt acts to disguise their crimes. This phenomenon is a global phenomenon (apvaindonesia.com). In addition, the more foreign currencies that enter Indonesia through money changer, the higher 
the foreign exchange earnings (Zebua, 2016: 87). Thus, the exchange rate against foreign currencies will have an impact on the quality of financial reporting.

The quality of the financial reporting reflects the quality of information that will influence the decision-making, as it is based on information that has been prepared in a transparent, accountable and qualified manner (Payamta, 2006). Quality reports present all information about the company's business in a relevant and reliable way (Sari and Suaryana, 2014). Good quality financial reports if they meet relevant normative requirement, are reliable, comparable, and understandable. The financial reporting are one form of organizational accountability to stakeholders (Astika and Yasa, 2018, Karsana and Suaryana, 2017). Purba and Suaryana, (2018) also state that qualified financial reporting are those that indicate the actual state of the company.

\section{LITERATURE REVIEW}

Stewardship Theory. This study is based on stewardship theory with the assumption that managers act responsibly according to the needs of interested parties (Donaldson and Davis, 1991). In carrying out its responsibilities, Steward uses all of his abilities and expertise for organizational goals (Anton, 2010). This theory assumes that management with high integrity, honesty and able to act with full responsibility to carry out the best actions aimed to meet the needs of stakeholders and shareholders. Stewardship Theory states that managers will be more concerned with credibility or public trust. Managers are described as good stewards (Huse, 2007), where managers are faithful to carrying out every task and responsibility. Managers are not motivated in material and money, but they are motivated by self-desire in self-actualization and gain satisfaction from the work done, and avoid conflict of interest.

In this research, stewardship theory becomes the basis to know that managers can create quality financial report. Where, the manager of a money changer company must have a commitment to carry out its duties and obligations to prevent business activities used for money laundering, terrorism financing or other crimes and to enhance professionalism in accordance with PBI 18/20/PBI/2016 concerning the activities of non-bank foreign exchange (www.bi.go.id), there by improving the quality of the company's financial reporting.

Good Corporate Governance. Good corporate governance is often defined as good leadership. Sumodiningrat (1999: 251) states that good corporate governance is a trustworthy effort. According to Bank Indonesia Regulations No. 8/4/ PBI/2006, five GCG principles, among others: transparancy is open information in executing decision making process; accountability is the clarity of functions and responsibilities for effective management; responsibility is the conformity of corporate management with applicable regulations; independency is the management of a company professionally without any influence or pressure from anywhere; fairness that is justice and equality in fulfilling the rights of stakeholders.

Tri Hita Karana Culture. Etymologically, Tri Hita Karana's Tri is three, Hita means prosperity, and Karana is the cause, consisting of Parahyangan (spiritual environment), Pawongan (social environment) and Palemahan (natural environment). The concept of Tri Hita Karana can be interpreted as three harmonious relationships between human and God, human with other human, and human being with environment to achieve safety and peace of the universe (Kaler, 1983; Surpha, 1991; Dalem, 2007; Palguna, 2007; Agung, 2009 and Pranata et al., 2017). THK is a concept or often referred to as a Hindu community philosophy in Bali. The universal concept of THK and the concept applied in a social system can be measured basically. THK is a philosophy of togetherness and harmonization that does not recognize race, ethnic, religion, ancestry and is contained in all religious teachings in the world (Arif, 1999 and Pusposutardjo, 1999 in Suardhika, 2011). This shows that THK culture in business is a testament to the values contained in the national culture has been used and implemented in organizational culture practices (Suardhika, 2011). The cultural values associated with THK disclosed by Adhiputra (2009) in Sujana et al. (2015) are:

- Parahyangan encompasses Moksartam jagathitaya caiti dharma which implies the image of the living human in the world aims to achieve the inner and outer welfare; 
Wyapi-wiyapaka is as a principle of human always remember that God is always everywhere and always remember prayer or worship; Rwa bhineda (appreciating differences/two different ones) is fostering an attitude of mutual understanding between people.

- Pawongan includes Tri kaya parisudha, which teaches people to always think (manacika), say (wacika), and act or do (kayika) is good; Purusartha chess, which is the successful dharma (good deeds), artha (material / wealth), kama (pleasure), moksa (balance / harmony) in everyday human life; Tat twam asi (the concept of love, and realizing the life of all living things as a whole unity) is to teach people to always avoid violence and cruelty; Karma phala (causal law); and Tri guna (three characters / behavior): satwam (wise, honest, loyal), rajas (full of lust / greed), tamas (lazy).

- Palemahan encompassing the paros paros salunglung sabayantaka saharpanaya, which implies the value of attitudes, human learning to understand and practice tolerant life, as well as the cultural value of anuduhkna ajnyana sandhi, which implies that human beings will not harm and impersonate nature or the environment.

Quality of Financial Reporting. The quality of financial reporting is still varied, but in principle the quality of financial reporting relates to the overall performance of the company reflected in the company's earnings. This view holds that high quality earnings are reflected in sustainable profits for a long period (Yasmeen and Hermawati, 2015).

Based on Government Regulation No. 71 of 2010 states, to produce financial reports that benefit the users, the information contained in the report must be qualified and useful in decision making. The quality of these financial reporting is reflected in qualitative characteristics. The normative prerequisites required for government financial reporting to meet the desired qualities of relevance, reliability, comparability and comprehensibility.

The Effect of Good Corporate Governance on Quality of Finnacial Reporting. Theoretically, Sumodiningrat (1999: 251), states that good corporate governance is a trustworthy effort as a good leader. Empirically, Sahay and Kuldeep (2015) stated that good corporate governance is very relevant and important to be found in the holy book in India. Where, managers have the potential and significant impact on corporate governance that impact on the quality of financial statements (Cohen et. al., 2004). This is supported by research Mulyawan et al. (2017), whereby GCG positively affects the performance of LPD. Emile et al. (2014) found that Good Corporate Governance practice is considered very important for the company because it can reduce risk, attract investors and improve company performance. In addition, GCG is said to have an effect on the reliability of financial reporting (Novatiani and Fatimah, 2013).

$\mathrm{H}_{1}$ : Good Corporate Governance is positive effect on Quality of Financial Reporting.

The Effect of Tri Hita Karana Culture on Quality of Financial Reporting. Theoretically, Tri Hita Karana explains that the tradition of Hindu society in Bali both individually and organization group in everyday life put forward the principle of togetherness, harmony, and balance reflected in three dimensions, namely parahyangan, pawongan. and palemahan (Windia and Dewi, 2007: 23 in Suardhika, 2011). Empirically, Kepramareni et al. (2014), states that responsibility of the financial reporting quality is implemented holistically. Kepramareni also concluded that the accountability of the report was conducted in two forms, ie, sekala and niskala. This proves that accountability is done not only in relation to humans and the environment, but also with God. Magesh and Prasad (2015) concluded that emotional and spiritual balance would build an individual relationship with the organization around it. This harmonious relationship will help improve the quality of financial reporting because of the high integrity of corporate leaders.

$\mathrm{H}_{2}$ : Tri Hita Karana Culture is positive effect on Quality of Financial Reporting.

\section{METHODS OF RESEARCH}

This study uses questionnaires as data sources because this study examines one's perception. Respondents in this study are manager, accounting, owner and teller. Questionnaires were distributed to the headquarters of the money changer company. This is 
because research respondents can be covered at head office. This study uses only one teller in the head office, because it is considered able to represent respondents. These respondents were also considered capable of providing the appropriate answers to those required in the study. The questionnaire of this study used a likert scale of 1 to 5 . Each question has five answer options, ranging from "strongly disagree" to "strongly agree," which is then converted to a number from one to "strongly disagree" to five for answers "strongly agree". Likert scale is used in order to facilitate the respondent to choose alternative answers.

he population in this study amounted to 88 companies. Meanwhile, the samples in this study were conducted by saturated sampling technique known as census, where all members of the population were sampled. Thus, the sample in this study is equal to the number of population that is as many as 88 companies.

Before performing the analysis, the classical assumption test is performed, such as normality test, heteroscedasticity and multicollinearity. In addition, tested the validity and reliability. To test the hypothesis, in this study used multiple regression analysis model with equation formula as follows:

$$
\text { Quality of Financial Reporting }=\alpha+\beta 1 \mathrm{GCG}+\beta 2 \mathrm{THK}+\varepsilon
$$

Where:

$\alpha=$ constants;

$\beta=$ regression coefficient;

GCG = Good Corporate Governance;

THK = Tri Hita Karana Culture;

$\varepsilon=$ error.

Operationalization of Variables:

Dependent variable. Dependent variable of this research is Quality of Financial Reporting. The dependent variable was measured by the questionnaire adopted from the Puspitawati (2016) study. This dependent variable uses indicators based on qualitative characteristics in Government Regulation No. 71 of 2010, namely: relevant, reliable, understandable, and comparable.

Independent variables. Good Corporate Governance variables were measured using questionnaires adopted from Mulyawan et al. (2017). This variable uses indicators based on GCG principles, namely: transparency, accountability, responsibility, independency and fairness. While Tri Hita Karana Culture variables were measured using questionnaires adopted from Suardhika (2011). This variable uses indicators based on three dimensions of THK culture, namely: Parahyangan, Pawongan and Palemahan.

\section{RESULTS AND DISCUSSION}

Instrument Data. This study uses the unit of analysis in the form of respondents from the sample companies because of the research respondents who gave the perception of the variables studied. Therefore, the analysis conducted using answers from respondents as many as 288 questionnaires. This research is feasible to proceed because based on the central limit of theorem, the minimum number of samples to find the normal curve at least reached the minimum of respondents as much as 30 (Sugiyono, 2013: 86).

Table 1 - Instrument Data

\begin{tabular}{|l|c|}
\hline Explanation & Total \\
\hline Distributed questionnaire & 352 \\
The questionnaire did not return & 64 \\
The questionnaire is returned and used & 288 \\
\hline Usability response rate & \\
\hline $\mathbf{2 8 8} / \mathbf{3 5 2} \mathbf{1 0 0} \%=\mathbf{8 2} \%$ &
\end{tabular}


Total of questionnaires distributed on the money changer are 352 questionnaires. This is because the sample of research are 88 companies, and for each company distributed 4 questionnaires, namely for owners, managers, accounting and teller. Based on the distributed questionnaires, only 72 money changer companies filled out the research questionnaires, so the questionnaire returned 288 questionnaires (usability response rate $=82 \%$ ).

Characteristics of Respondent. Characteristics of respondents are the last level of education taken from each respondent. In the characteristics of education level, it can be said that the respondent has an adequate level of education. Table 2 shows respondent characteristics based on education level in money changer.

Table 2 - Characteristics of Respondent

\begin{tabular}{l|c|c}
\hline \multicolumn{1}{c}{ Explanation } & $\begin{array}{c}\text { Total Respondent } \\
\text { (People) }\end{array}$ & $\begin{array}{c}\text { Percentage } \\
(\%)\end{array}$ \\
\hline Level of Education & 71 & \\
SMA & 52 & 24,65 \\
Diploma 3 & 142 & 18,06 \\
S1 & 23 & 49,31 \\
S2 & $\mathbf{2 8 8}$ & 7,98 \\
\hline Total & & $\mathbf{1 0 0}$ \\
\hline
\end{tabular}

Source: data processed (2018).

Table 3 - Validity Test

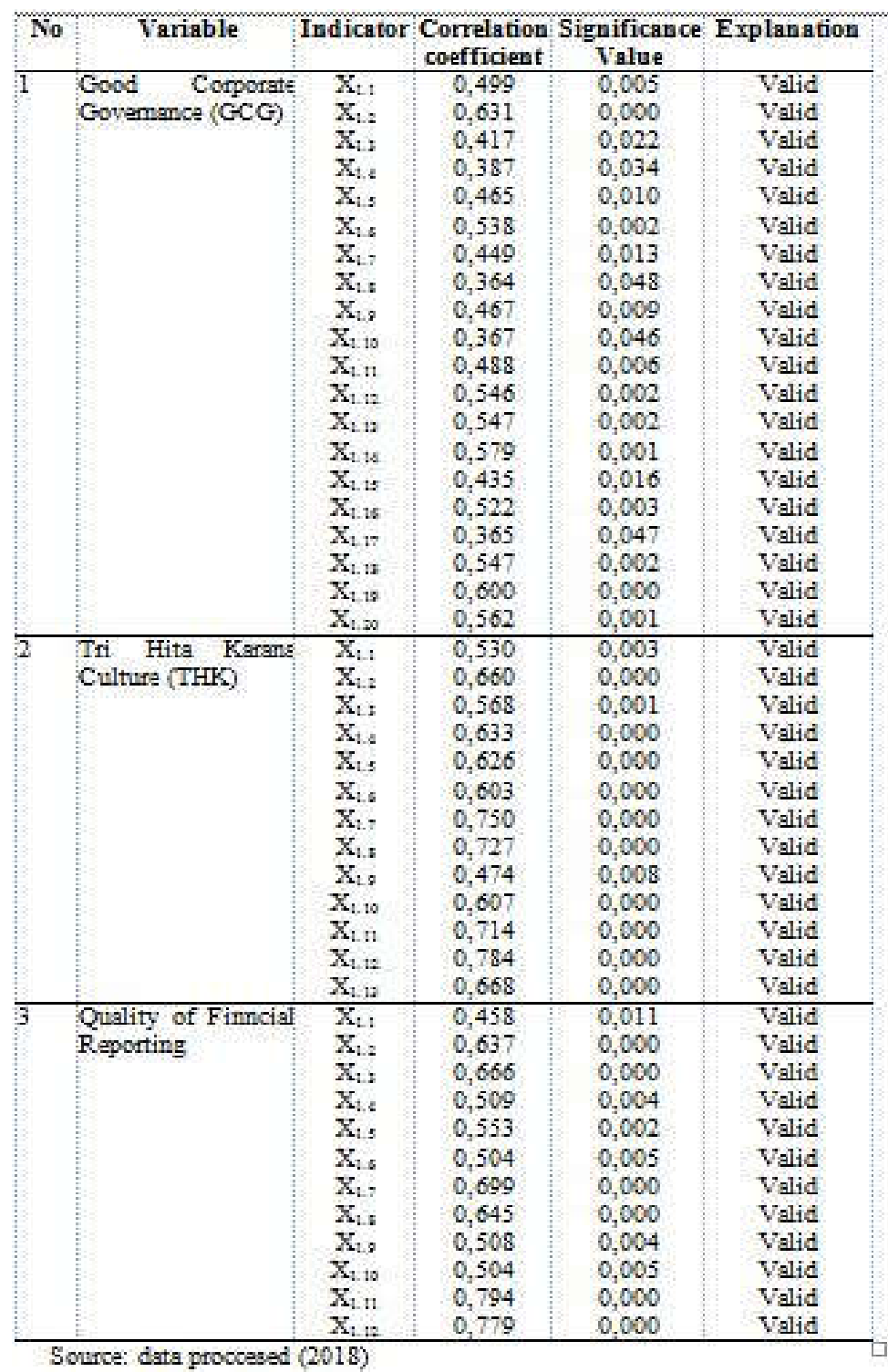


Characteristics of respondents based on the level of education shows that the number of respondents as many as 288 people divided into several levels of education, which is 71 people $(24.65 \%)$ last education high school, as many as 52 people $(18.06 \%)$ last education Diploma 3, as many as 142 people $(49.31 \%)$ have recent education S1, and 23 people $(7.98 \%)$ have recent education $\mathrm{S} 2$.

Validity Test. Validity test in this research is done in three research variables, that is good corporate governance, tri hita karana culture and quality of financial reporting. Validity test is conducted to measure whether or not a questionnaire is valid.

Based on Table 3, each question of each variable qualifies the validity or can be said to be valid. This is because each question of the research variables has a significance value of less than 0.05 .

Reliability Test. Reliability test is done in three research variables, namely good corporate governance, tri hita karana culture and quality of financial reporting. Testing reliability of the instrument shows the extent to which a measurement of the same symptoms. Reliable instruments are instruments used multiple times to measure the same object and produce the same data or answers. Instruments are said to be reliable if they have a Cronbach's alpha value greater than 0.60 (Ghozali, 2011: 47-48).

Table 4 - Reliability Test

\begin{tabular}{|l|c|c|}
\hline \multicolumn{1}{|c|}{ Variable } & Cronbach's alpha & Explanation \\
\hline Good Corporate Governance (GCG) & 0,823 & Reliabel \\
Tri Hita Karana Culture (THK) & 0,854 & Reliabel \\
Quality of Financial Reporting & 0,839 & Reliabel \\
\hline
\end{tabular}

Source: data processed (2018).

Based on Table 4, all research instruments are said to be reliable. The overall value of Cronbach's alpha greater than 0.60 indicates that such measurements can provide consistent results when re-measurements of the same subject at different times.

Normality Test. Normality test aims to test whether the data is normally distributed or not. A good regression model is a regression model that is normally distributed or close to normal. Normality test used Kolmogorov-smirnov test. Data is normally distributed if it has a significance level above 0.05 (Asimp Sig (2-tailed)> 0.05) (Ghozali, 2011: 160).

Table 5 - Normality Test

\begin{tabular}{|l|c|}
\hline & Unstandaridized Residual \\
\hline $\mathbf{N}$ & 288 \\
Kolmogorov-smirnov & 1,137 \\
\hline Asimp. Sig (2-tailed) & 0,151 \\
\hline
\end{tabular}

Source: data processed (2018).

Based on Table 5, the value of Asimp Sig (2-tailed) of the normality test is 0.151 or greater than 0.05 . This shows that the model in this study normal distribution, so that data can be used in research.

Heteroscedasticity Test. Heteroscedasticity test aims to determine whether the regression model does not occured inequality of variant and residual one observation to another observation. If the variant of the residual one observation to another observation remains, it is called homocedasticity and if different is called heteroscedasticity.

Table 6 - Heteroscedasticity Test

\begin{tabular}{|l|c|c|c|}
\hline Variable & $\mathbf{t}$ & Sig & Explanation \\
\hline GCG & 1,787 & 0,075 & Non-Heteroscedasticity \\
THK & 1,865 & 0,063 & Non-Heteroscedasticity \\
\hline
\end{tabular}

Source: data processed (2018). 
Heteroscedastisity test in this research used Glejser test. This method is done by correlating the residual value of regression result with each independent variable. The regression model does not contain any heteroscedasticity if the probability is above the 0.05 trust level (Ghozali, 2011: 139).

Based on the heteroscedasticity test in Table 6, the significance value of the dependent variable, Absolute Residual (ABRES), is indicated by the t-significance value which is all greater than alpha $(a=0.05)$. So it can be concluded that the regression model found no symptoms of heteroscedasticity.

Multicolinearity Test. Multicollinearity test aims to determine whether in the regression model there is a correlation between independent variables. A good regression model is a regression model that is independent of the correlation between independent variables. The multicollinearity test is measured by the Variance Inflation Factor (VIF) and tolerance values.

Table 7 -Multicolinearity Test

\begin{tabular}{|l|c|c|}
\hline \multicolumn{1}{|c|}{ Variable } & Tolerance & VIF \\
\hline Good Corporate Governance (GCG) & 0,835 & 1,197 \\
Tri Hita Karana Culture (THK) & 0,835 & 1,197 \\
\hline Source: data processed (2018)
\end{tabular}

Source: data processed (2018)

Based on the results in Table 7, it can be seen that no independent variable has tolerance value less than 0.10 and VIF value more than 10 . Analysis shows that there are no symptoms of multicolinearity to research variables, so feasible use in subsequent research.

Descriptive statistics. Descriptive statistics in this study were used to provide information on research characteristics, such as mean and standard deviation. Average measurement is the most common way to set the central value of a data distribution, whereas the standard deviation is the difference in the value of the data studied with the average value.

Table 8 - Descriptive statistics

\begin{tabular}{|l|c|c|c|c|c|}
\hline Variable & N & Min. & Max. & Mean & $\begin{array}{c}\text { Std. } \\
\text { Deviation }\end{array}$ \\
\hline GCG & 288 & 34,10 & 92,37 & 70,6399 & 11,35619 \\
THK & 288 & 23,80 & 54,92 & 46,1161 & 7,23585 \\
KLK & 288 & 29,09 & 58,86 & 44,4328 & 6,96143 \\
\hline
\end{tabular}

Source: data processed (2018)

Based on the test results in Table 8, it can be seen that the average value of GCG of 70.6399 is close to its maximum value. The GCG variable in this study has 20 questions. The results of this analysis show that respondents provide opinions with a score close to the maximum value indicating that the money changer in Badung regency already apply GCG well in every business process, especially to produce quality financial reporting.

The average THK score of 46.1161 shows the average answer of the respondents is almost close to its maximum value. THK variable consists of 13 questions. The result of this analysis shows that the money changer company in Badung Regency has implemented and implemented Tri Hita Karana Culture (parahyangan, pawongan and palemahan) in every business activity.

The average value of the quality of financial reporting of 44.4328 shows the average answer of the respondents almost close to its maximum value. This indicates that the average quality of the financial reporting of money changer companies in Badung Regency shows the financial reporting of good quality and qualified financial reporting are relevant, reliable, comparable and understandable.

Regression Result. Multiple linear regression analysis aims to determine the effect of GCG on the Quality of Financial Reporting and the effect of THK on the Quality of Financial 
Reporting, the multiple linear regression analysis is used because the independent variables are used more than one. Below is the result of multiple linear regression analysis in Table 9.

Table 9 - Multiple Linear Regession Analysis

\begin{tabular}{|c|c|c|c|c|c|}
\hline $\begin{array}{l}\text { Variable } \\
\text { Variable }\end{array}$ & $\begin{array}{r}\text { Unstand } \\
\text { Coeffi }\end{array}$ & $\begin{array}{l}\text { dardized } \\
\text { iicients }\end{array}$ & $\begin{array}{c}\text { Standardized } \\
\text { Coefficients }\end{array}$ & t & Sig. \\
\hline (Constant) & B & Std. Error & Beta & t & Sig. \\
\hline (Constant) & 12,351 & 2,440 & - & 5,062 & 0,000 \\
\hline GCG & 0,285 & 0,031 & 0,465 & 9.195 & 0,000 \\
\hline THK & 0,259 & 0,049 & 0,269 & 5.315 & 0,000 \\
\hline R Square & 0,390 & & & & \\
\hline Adjusted R Square & 0,386 & & & & \\
\hline$F_{\text {hitung }}$ & 91,271 & & & & \\
\hline Sig F & 0,000 & & & & \\
\hline
\end{tabular}

Goodness of fit model shown at $F$ value equal to 91.271 with significance level 0.000 and smaller than $a=0.05$, hence this research model is feasible to be used to verify hypothesis which is formed or in other words this research model is fit model. Meanwhile, the value of Adjusted $R$ Square is 0.386 , which means that 38.6 percent of the dependent variable is the quality of financial statements can be explained by GCG and THK variables, while the remaining 61.4 percent is influenced by other variables not included in this research model.

Based on result of hypothesis test which shown at t-test value for GCG variable is equal to 9.195 with level of significance 0.000 , that is less than 0.05 and has positive regression coefficient equal to 0.285 . This means that GCG has a positive effect on the quality of financial reporting of money changer in Badung Regency, so $\mathrm{H} 1$ is accepted and $\mathrm{HO}$ is rejected. This is in line with research conducted by Anggreni et al. (2018) that GCG has a positive effect on the quality of financial reporting. Similarly, Novatiani and Fatimah (2013) argue that GCG affects the reliability of financial reporting, where the reliability of financial reporting is one of the normative prerequisites of quality financial reporting.

Based on result of hypothesis test shown on t-test value for THK variable is 5.315 with significance level 0.000 , less than 0.05 and has positive regression coefficient 0.259 . This means that THK has a positive effect on the quality of financial reporting of money changer in Badung regency, so that $\mathrm{H} 2$ is accepted and $\mathrm{HO}$ is rejected. This is in line with research conducted by Kepramareni et al. (2014), where the MGPSSR organization is used as its research location, that responsibility of the financial reporting quality is implemented holistically. Magesh and Prasad, (2015) also concluded that emotional and spiritual balance would build an individual relationship with the surrounding organization. A harmonious relationship will help improve the quality of financial reporting because of the high integrity of corporate leaders.

\section{CONCLUSION}

GCG has a positive effect on the quality of money changer's financial report in Badung Regency. This result means the better the implementation of GCG, the higher the quality of financial reporting. In other words, that with the implementation of good governance or GCG, will improve the quality of financial reporting that impact on the credibility and public trust and trust of stakeholders for decision making.

THK culture has a positive effect on the quality of financial reporting money changer in Badung regency. This result means the better the application and understanding of THK culture, the higher the quality of financial reporting. In other words, that with the application and understanding of THK culture, the quality of financial reporting will increase because of the harmonious relationship between human and God, human relationships with humans, 
and human with the environment. Thus, the local culture of Bali can be a guide to improve the quality of financial reporting.

This research has limitation, where the value of Adjusted $R$ Square from this research is equal to 0.386 which means that $38.6 \%$ dependent variable that is financial report quality of money changer can be explained by GCG variable and THK culture, while the rest equal to 61.4 percent influenced by variable which is not included in the research model. Thus, this is an opportunity for future researchers to develop this research in the future. In addition, the unique culture of THK in Bali is still an interesting thing to be studied.

\section{REFERENCES}

1. Afrianto, D. (2017). Tata Kelola Perusahaan Indonesia termasuk Peringkat Bawah di Asia Tenggara. Artikel. http://economy.okezone.com, diakses tanggal 17 April 2017

2. Agung, A. A. G. (2009). Bawa Tri Hita Karana Go World, Bali Post, Minggu Pon, 5 April 2009. http://lingkunganhidupmenuruttrihitakarana.blogspot.co.id diakses tanggal 17 April 2017.

3. Anggreni, N. M. M., Widanaputra, A. A. G. P. and Putri, IGAM. A. D. (2018). Pengaruh Good Governance dan Kompetensi Sumber Daya Manusia pada Kualitas Laporan Keuangan di Kota Denpasar. E-Jurnal Akuntansi Universitas Udayana, Vol 22.1, 352-380

4. Anton, A. (2010). Dasar-dasar Manajemen. CV Pustaka Setia: Bandung.

5. Astika, I.B. P. and Yasa, G. W. (2018). Kemampuan Komitmen Organisasi Memoderasi Kompetensi Pejabat Penatausahaan Keuangan dan SPI pada Kualitas Laporan Keuangan Kota Denpasar. E-Jurnal Akuntansi Universitas Udayana, Vol 22.1, 301-325

6. Chui, A. C.W., Lloyd, A. E. and Kwok, C. C. Y. (2002). The determination of capital structure: is national culture a missing piece to the puzzle?. Journal of International Business Studies 33, 99-127

7. Cohen, J., Ganesh, K., and Arnie, W. (2004). The Corporate Governance Mozaic and Financial Reporting Quality. Journal of Accounting Literature

8. Dalem, A.A.G. R. (2007). Implementasi Tri HitaKarana dalam bidang Pariwisata Menuju Pembangunan Berkelanjutan. Jurnal lingkungan Hidup Bumi Lestari PPLH-UNUD Denpasar, Vol. 7, No. 1, hal. 78-84

9. Donaldson L and Davis, (1991). Stewardship Theory or Agency Theory: CEO Governance and Shareholder Return. Australian Journal of Management 16: 49-64

10. Ghozali, I. (2011). Aplikasi Analisis Multivariate dengan Program SPSS. Badan Penerbitan Universitas Diponegoro: Semarang.

11. Guiso, L., Sapienza P. and Zingales L. (2008). Social capital as good culture. Journal of the European Economic Association 6, 295-320

12. (2009). Cultural biases in economic exchange?. Quarterly Journal of Economics 124, 1095-1131

13. Huang, R. (2008). Tolerance of uncertainty and the growth of informationally opaque industries. Journal of Development Economics 87, 333-353

14. Huse, M. (2007). Board, Governance, and Value Creation: The Human Side of Corporate Governance. Cambridge University Press: Cambridge

15. Kaler, G.K. (1983). Butir-butir Tercecer Tentang Adat Bali Vol II (Scattered Thoughts on Balinese Custom Vol II). Bali Agung: Denpasar

16. Karsana, I W. and Suaryana, I G. N. A. (2017). Pengaruh Efektivitas Penerapan SAP, Kompetensi SDM, dan SPI pada Kualitas Laporan Keuangan Pemerintah Kabupaten Bangli. E-Jurnal Akuntansi Universitas Udayana, Vol. 21.1, 643-670

17. Kepramareni, P., Sudarma, M., Irianto, G. and Aulia F. R. (2014). Sekala and Niskala Accountability Practices in the Clan Based Organization MGPSSR in Bali Indonesia. Scientific Research Journal, Vol II Issue II

18. Magesh, S. and Prasad, V. K. (2015). An Approach to Corporate Governance by an Individuals Self Consciousness and Integrated Advancement. Scope International Journal of Science, Humanities, Management and Technology, Vol 1 Issue 1 pp 1-5 
19. Mulyawan, I P. A., Wirama, D. G., and Badera, I D. N. (2017). Budaya Tri Hita Karana sebagai Pemoderasi Pengaruh Prinsip Good Corporate Governance pada Kinerja LPD. Jurnal Ekonomi dan Bisnis Universitas Udayana, 6.8: 3193-3222

20. Novatiani, R. A. dan Fatimah, J. (2013). Pengaruh Penerapan Good Corporate Governance terhadap Keandalan Laporan Keuangan. repository.widyatama.ac.id

21. Palguna, A.A.B. (2007). Budaya Tri Hita Karana dan Trikaya Parisudha. Wahana, Edisi No. 59 Th. XXIII Nopember 2007, Hal. 14-17.

22. Payamta, (2006). Pengaruh Kualitas Auditor, Indepedensi, dan Opini Audit terhadap Kualitas Laporan Keuangan. Jurnal Bisnis dan Manajemen, Vol 6 No 1 hal 81-90.

23. Peraturan Bank Indonesia No. No. 8/4/PBI/2006 access on https://www.bi.go.id

24. No. 18/20/PBI/2016 access on https://www.bi.go.id

25. No. 19/10/PBI/2017 access on https://apvaindonesia.com

26. Peraturan Pemerintah No 71 tahun 2010

27. Pranata, K. A., Sri, A.A.P and Putra, A.M. (2017). Penerapan Konsep Tri Hita Karana di The Trans Hotel Resort Bali. Jurnal Kepariwisataan dan Hospitalitas Vol 1 No. 1 April 2017.

28. Purba, I A. C. dan Suaryana, IGNA. (2018). Kualitas Laporan Keuangan, Asimetri Informasi dan Efisiensi Investasi pada Perusahaan Pertambangan. Jurnal IImiah Akuntansi dan Bisnis, Vol. 13, No. 1

29. Putri, IGAM. A. D. (2012). Peranan Good Corporate Governance dan Budaya Terhadap Kinerja Organisasi. Jurnal IImiah Akuntansi dan Bisnis, Vol. 7, No. 2.

30. Ulupui, IGKA. (2017). Pengaruh Good Corporate Governance dan Budaya Tri Hita Karana pada Kinerja BPR. Jurnal IImiah Akuntansi dan Bisnis, Vol 12 No.1

31. Puspitawati, D. (2016). Analisis Faktor-Faktor yang Mempengaruhi Kualitas Laporan Keuangan Pemerintah Daerah. Tesis, Universitas Lampung: Bandar Lampung.

32. Sari, L. I. N. and Suaryana. IGNA. (2014). Pengaruh Kualitas Laporan Keuangan pada Efisiensi Investasi Perusahaan Pertambangan. E-Jurnal Akuntansi Universitas Udayana, 8.3, 524:537.

33. Sahay, M. and Kuldeep K. (2015). Invigorate Corporate Board Through Indian Scriptures. Ownership \& Control, Vol 12 Issue 3 Spring 2015 National Practices Of Corporate Governance

34. Shleifer (1997). A Survey of Corporate Governance. Journal of Finance, 52(2):737-783.

35. Suardikha, I M. S. (2011). Pengaruh Implementasi Budaya Tri Hita Karana terhadap Penggunaan Sistem Infromasi Akuntansi dimediasi Keyakinan Diri atas Komputer, Keinovatifan Personal, Persepsi kegunaan, dan Persepsi Kemudahan Penggunaan pada Bank Perkreditan Rakyat di Bali. Disertasi, Universitas Brawijaya

36. Sudarma, M. (2013). Revealing The Agency Cost, Management Behaviour in the Practice of Tri Hita Karana Culture (A Study at LPD of Pakraman Village in Denpasar Bali). IOSR Journal of Business and Management Vol 10 Issue 5 pp 54-61

37. Sugiyono. (2013). Metode Penelitian Bisnis (PendekatanKuantitatif, Kualitatif, dan R\&D). Alfabeta: Bandung.

38. Sumodininggrat, G. (1999). Pemberdayaan Masyarakat dan Jaring Pengaman Sosial. Gramedia Pustaka Utama: Jakarta

39. Surpha, W. (1991). Eksistensi Desa Adat di Bali (The Existence of Desa Adat in Bali). Upada Sastra: Denpasar

40. Tabellini, G. (2008). Institutions and culture. Journal of the European Economic Association 6, 255-294

41. Todorovic, I. (2013). Impact of Corporate Governance on Performance of Companies. Monyenegrin Journal of Economics, 9 (2): 47-53

42. Wirajaya, G.A. (2014). The Accountability and the Dimension of Tri Hita Karana. Scientific Research Journal, Vol II Issue VIII Agustus 2014, ISSN 2201-2796

43. Yasmeen, D. and Hermawati, S. (2015). Pengaruh Good Corporate Governance terhadap Kualitas Laporan Keuangan pada Perusahaan Manufaktur. Jurnal Ekonomi dan Bisnis Vol 20 No 1, April 2015.

44. Zebua, M. (2016). Inspirasi Pengembangan Pariwisata Daerah. Deepublish: Yogyakarta. 